\title{
Patent applications in drug delivery
}

\begin{tabular}{|c|c|c|c|c|c|}
\hline Patent \# & Subject & Assignee & Author & Date & Status ${ }^{\star}$ \\
\hline WO 974183 & $\begin{array}{l}\text { Vesicle with cationic lipid bilayer that includes viral fusion peptide; } \\
\text { used for delivery of genetic material to cells, especially for gene } \\
\text { therapy of cancer. leukemia, and viral infections. }\end{array}$ & Nika Health Products & $\begin{array}{l}\text { Glueck R, Klein P, } \\
\text { Waelti ER }\end{array}$ & $11 / 13 / 97$ & $\mathrm{~A} 1$ \\
\hline
\end{tabular}
coupled to histiding e.g., enterohemorrhagic $E$. coli, and as carriers for other antigens Military Medicine or drugs targeting the intestinal epithelium.

for the Advancement of Wachtel MR

(Rockville, MD)

US 5676943 Delivery of nerve growth factor to central nervous system by implanting encapsulated cells transfected with recombinant DNA; (Providence, RI) useful for treating neurodegenerative diseases and age-related cognitive defects.

US 5672359 Hard-capsule drug-delivery system for oral or vaginal administration; has fast-release outer coating and intermediateand slow-release compartments, giving both immediate and prolonged treatment.

WO 9734620 Excitation-secretory uncoupling peptide(s) for inhibiting neurotransmitter release; used particularly for treating muscle spasticity, and for delivering drugs specifically to neural cells.

US 5670483 Membranes formed by self-assembly of amphiphilic peptide(s); useful as biomaterial(s), separation matrices, drug delivery vehicles, etc.

WO 9733605 Isolated human occludin protein; useful for increasing drug delivery across endothelial or epithelial barriers, or for reducing tissue permeability.

WO 9732991 Recombinant adeno-associated virus vectors; used in gene therapy for treatment of solid tumors.

WO 9731938 Pyroglutamic acid or proline-initiated oligopeptide, for use in oral delivery of vulnerable active agents, e.g.. insulin, interferon, heparin, antibodies, antimicrobials, etc.

WO 9730730 Fine grain carriers for drug-delivery systems comprising, e.g., poly- Daiichi Pharm. $\mathrm{N}$-polyalkylacrylamide graft chain and polyacrylic acid graft chain. Co. (Tokyo)

US 5658247 lonosonic drug-delivery apparatus for treatment of large areas of Henley JL skin; includes iontophersis electrode with medicament carrier layer, and series of piezoelectric elements affixed to and overlying iontophoresis electrode.

DE 19605175 New quaternary amine compounds; useful in transport of biologically active substances or molecules into cells.

US 5656016 Ultrasonic drug-delivery system comprising signal generator, amplifier, and ultrasonic transducer, with acoustic coupling line to site of injection for transdermal injection into circulatory system using lower cost; optionally portable system having feedback loop and variable frequency to enhance penetration.

US 5654189 Pure cultures of stable postmitotic human neuronal cells, optionally including transfected genes, produced by treating NT2 cells with retinoic acid; useful as experimental models and for delivering therapeutic proteins.

US 5651976 Controlled-release compositions comprising hollow mineral microtubules of, e.g., cylindrite adsorbed with active agent, e.g., pesticide, antibiotic, peptide, hormone, or drug.

WO 9725342 New prodrugs tethered with glutathione analogs; used in drug-delivery systems, particularly for prodrugs that depend on glutathione S-transferase for activation, selectively treating target cells having elevated glutathione S-transferase isoenzyme(s).

WO 9722371 Polymers cross-linked by multiple electrophilic and nucleophilic groups; used as bioadhesives, or for, e.g., hard and soft tissue augmentation, preventing surgical adhesions, implant coating, or drug-delivery matrices.
CytoTherapeutics Inc.

Univ. Kentucky

Research Foundation

(Lexington, KY)

Univ. California

(Oakland, CA)

Massachusetts Inst. of Technology

(Cambridge, MA)

Yale Univ. (New

Haven, CT)

Avigen Inc., Mizuno M, Okada $\mathrm{H}$, Yoshida J

Emisphere

Technologies

(Hawthorne, NY)

Baetge EE, Emerich DF, 10/14/97 Gentile FT, Hammang JP, Lindner MD,Winn SR

Digenis GA, Noskova D 09/30/97

Montal M

$09 / 25 / 97$

Holmes T, Lockshin C, - 09/23/97

Rich A, Zhang S

Anderson JM,

09/18/97

A1

Van Itallie CM

Colosi PC, Kurtzman GJ 09/12/97 A2

Milstein SJ

09/04/97

Akashi M, Kikuchi H

08/28/97 A1

Kishida A, Sakuma S

$08 / 19 / 97$

A

Sourovoi A

Jung $G$, Sourovoi $A$

$08 / 14 / 97$

Abbott Laboratories

Ogden JE

08/12/97 A

(Abbott Park, IL)

Univ. Pennsylvania

Lee V, Pleasure S

08/05/97 A

(Philadelphia, PA)

US Navy

Gaber BP, Price RR

07/29/97

A

Terrapin Technologies

Kauvar LM, Lyttle MH

07/17/97

A1

(S. San Francisco, CA)

Collagen Corp.

(Palo Alto, CA)

Berg RA, Delustro FA,

$06 / 26 / 97$

A1

A

